\title{
ESTUDO DA CAMADA LIMITE ATMOSFÉRICA NA REGIÃO DE ANGRA DOS REIS ATRAVÉS DO MODELO DE MESOESCALA MM5 E DADOS OBSERVACIONAIS
}

\author{
José Francisco de Oliveira Júnior \\ Orientador: Dr. Luiz Cláudio Gomes Pimentel (UFRJ) \\ 272 p. - Tese (Doutorado) - Defesa 11.07.2008
}

RESUMO. Motivados pela fenomenologia existente no Complexo Nuclear Almirante Álvaro Alberto (CNAAA), Angra dos Reis - Rio de Janeiro, foram feitas avaliações climatológicas, sazonais, mensais e diárias da direção e velocidade do vento, estabilidade atmosférica, dos sistemas sinóticos num período de 26 anos e das forçantes na CNAAA. A estabilidade foi estimada por Pasquill-Gifford (P-G) e pelo Número de Richardson Bulk (Ri ${ }_{B}$ ). 0 Número de Froude (Fr) foi usado na caracterização do escoamento na região. As maiores freqüências da Passagem de Sistemas Frontais (PSF) foram em maio e setembro, enquanto o Sistema de Alta Pressão (SAP) em julho, setembro e novembro. Através das torres identificou-se a predominância de calmaria e ventos fracos, sendo a média de $2 \mathrm{~m} \cdot \mathrm{s}^{-1}$. As predominâncias nas torres $A 10$ e B foram devido às forçantes térmicas e em $A 60, A 100, C$ e D foram o vento de encosta, as brisas marítima-terrestre e a canalização forçada pelo terreno. 0 P-G e Ri $i_{B}$ mostrou que a condição estaticamente estável prevaleceu em relação às demais. 0 Fr mostrou que o regime é fraco, estável e ar estagnado. 0 modelo conceitual de Whiteman \& Doran (1993) e os dados de reanálise foram utilizados na identificação de alguns padrões relacionais entre o vento sinótico versus observado (A60 e C). Foram realizados dois experimentos com o MM5 para avaliar o seu desempenho num estudo de caso sob a atuação da SAP. As simulações utilizaram as parametrizações Eta/NOAH e GS/MULTI-LAYER. Ocorreram discrepâncias entre os resultados das parametrizações, e de um modo geral, a Eta/NOAH apresentou resultados mais concordantes com o observado que a GS/MULTI-LAYER.

ABSTRACT. Motivated by the existence phenomenology of the Almirante Álvaro Alberto Nuclear Complex (CNAAA), Angra dos Reis - Rio de Janeiro, climatological evaluations were made during a period of 26 years, including: seasonal, monthly and daily analyses of wind speed and direction, atmospheric stability, synoptic systems, and forcing mechanisms of the CNAAA. The stability was estimated considering Pasquill-Gifford (P-G) and Bulk Richardsons number $\left(\mathrm{Ri}_{\mathrm{B}}\right)$. Froudes number $\left(\mathrm{F}_{\mathrm{r}}\right)$ was used to characterize inlets/outlets flowing in the region. The highest transition Frequencies of Frontal Systems (FFS) were in May and September, while High Pressure System (HPS) occurred in July, September and November. Through towers calm and weak winds predominance were identified, with mean less than $2 \mathrm{~m} . \mathrm{s}^{-1}$. Prevailing directions in $\mathrm{A} 10$ and $\mathrm{B}$ towers were due to thermal forcing. Through towers A60, A100, C and D it was identified as main forcing: wind slopes, sea and terrestrial breezes and channeling forced by ground. $\mathrm{P}-\mathrm{G}$ criteria and $\mathrm{Ri}_{\mathrm{B}}$ showed that statically stable conditions prevailed in comparison to others. $\mathrm{F}_{\mathrm{r}}$ showed that the regime is weak, stable and stagnant air in CNAAA. The conceptual model proposed by Whiteman \& Doran (1993) and reanalysis of data were used to identify some relational patterns between synoptic wind versus observed (A60 and C). Two numerical experiments were carried out using MM5 to analyze their performance in a case study during on the SAP. Simulation settings with Eta/NOAH scheme GS/MULTI-LAYER parameterizations were used. Discrepancies were observed between parameterization and, in a general way, the Eta/NOAH presented results which are more consistent with observational as it was expected for a GS / MULTI-LAYER. 